\title{
Value Chain Structure Analysis as A Starting Point for Bamboo Enterprise Development: Lessons from Gunungkidul, Indonesia
}

\author{
Marcellinus Utomo ${ }^{1, *}$, Levina Pieter ${ }^{1}$, and Carmen M. Siagian ${ }^{2}$ \\ 1 Research and Development Institute of Agroforestry Technology, FORDA, MoEF, Indonesia \\ 2 LPPM Universitas Kristen Indonesia, Cawang, East Jakarta, DKI Jakarta, Indonesia \\ * Correspondence author: marcell.utomo@gmail.com
}

\begin{abstract}
The economic contributions of rural enterprises in Indonesia are significant to support local people's livelihoods, although it remains at micro to medium levels. One small-scale enterprise, which remains understudied and receives little policy attention, is the bamboo enterprise. Gunungkidul Regency in Yogyakarta Special Province, a central region in Java Island, Indonesia, have many bamboo enterprises, creating various products that support some 6,500 jobs. This research is conducted as a case study of the Gunungkidul Regency. A value chain perspective was used to study three bamboo-based enterprises' value chain structure: kitchen utensils, bamboo toy handicraft, and chemically treated bamboo. The snowball concept was used until the data was saturated. In total, 86 respondents were interviewed. The traditional chain was dominant. The longest value chain and the highest number of actor levels were bamboo toy handicrafts, and the shortest and smallest actor level was the chemically treated bamboo. Most channels were in the toy handicraft chain in the production flow, then kitchen utensils, and chemically treated bamboo. The credit payment method is prevalent in financial flow, and trust has been widely established between actors. The information flow related to price was imbalanced. In each chain, collaboration in the raw material segment was weak. The lack of willingness of artisans to be more productive and the weak cooperation among artisans, coupled with the lack of support from the government seems to be obstacles to the development of bamboo as a small to medium enterprise in Gunungkidul.
\end{abstract}

Keywords: bamboo; value chain; structure; policy; Gunungkidul

\section{Introduction}

Non-wood forest products (NWFPs) started attracting global attention between the late 1980s and early 1990s. Attention to NWFPs increased because of its significant livelihood and welfare contributions for forest dwellers (Arnold \& Pérez, 2001) and people outside forests (Sunderlin et al., 2005). During that period, attention to environmental issues has also risen, especially related to rural poverty and deforestation issues. The concept of sustainable development also emerged during this time (Belcher et al., 2005). Peters et al. (1989) findings of NWFP valuation have opened up a global perspective that NWFPs' values were higher than timber in the Amazon. Similar findings have also been revealed in Asia (Kar \& Jacobson, 2012; Mahapatra \& Tewari, 2005; Tewari, 2000).

The economic contributions of NWFPs for households are significant (Ambrose-Oji, 2003; Bhattacharya \& Hayat, 2004). Some research has proved that income from NWFP utilization is strongly related to alleviate poverty and create jobs (Fu et al., 2009; Mekonnen et al., 2013; Quang \& Anh, 2006; Tewari, 1998). NWFPs also have an essential role in providing medicine, cosmetic, subsistence needs, energy, and cultural material (Ingram, 2010). The dependence of NWFPs for poor society is higher than for prosperous society (Arnold \& Pérez, 2001; Belcher et al., 2005; Heubach et al., 2011; Kar \& Jacobson, 2012). Schreckenberg et al. (2006) asserts that there are three contributions of NWFP for poverty alleviation, viz. safety net, gap filler, and NWFPs contribute $50 \%$ of household income. 
According to Forestry Ministerial Decree No. P. 21/ Menhut-II/ 2009, in Indonesia NWFPs contribute to about $90 \%$ of forest value. Like many other tropical countries where NWFPs have social and cultural importance (Yadav \& Dugaya, 2013), NWFPs also has a significant economic contribution, particularly for forest-dependent people in Indonesia who remain marginalized in the development agenda. To optimize NWFPs contribution to support forest-dependent people's livelihoods and alleviate poverty, research in the NWFP value chain is timely. Moreover, the commodity remains understudied.

Value chain research has been applied in many studies globally. It can be used in many ways (Kaplinsky \& Morris, 2000) and by and for any actors in the chain (Humphrey \& Schmitz, 2002; Kaplinsky et al., 2003; M4P, 2008; Rich et al., 2011). Value chain research on investment mostly focuses on upgrading and development (Humphrey \& Navas-Alemán, 2010), especially in supporting small-scale farmers and producers in rural areas where they are mainly categorized as disadvantaged actors in the chain. Therefore, VCA has become a typical methodology relevant to livelihood improvement and poverty reduction projects (Arshad \& Reza, 2012; Mitchell et al., 2009).

Bamboo is an NWFP whose contribution to the economy, environment, and poverty becomes progressively important (Lobovikov et al., 2007), and remains perceived as the poor man's wood (Arshad \& Reza, 2012). However, INBAR (2009) asserts that about two billion people use bamboo for their daily lives. Bamboo is also useful for creating traditional, modern, and advanced products (Van der Lugt, 2008), and it is an enduring and versatile resource (Pande \& Pandey, 2008). Those factors collectively highlight that bamboo is an essential commodity to be developed and better understood.

In Indonesia, bamboo has a considerable contribution to livelihoods, particularly in rural areas. Bamboo-based enterprises have been generating job opportunities, likewise in other countries (Anitha, Muraleedharan, Santheep, Thomas, \& Sreelakshmi, 2008; Benton, 2014; Mekonnen et al., 2014; Moktan et al., 2009; Rana et al., 2010; Rao et al., 2009; Wang et al., 2008). Indonesia also has 143 bamboo species (Widjaja \& Kartikasari, 2001). This can be capitalized on to improve its contribution to livelihoods.

Indonesia is mainstreaming NWFPs development in its agenda. Bamboo is one of the priority commodities that attract more concern. The contribution of bamboo to rural development and livelihoods is evident in the bamboo-based enterprise in particular. Today, this business is mostly at a small-scale level. However, it is an integral part of the creative economy. Bamboo, wood, and rattan are the primary resources for handicraft industries, which contribute $18 \%$ to the gross domestic product from the creative economy sector (Sadilah, 2010). A report from the Directorate General of Watershed Management and Social Forestry in 2010 shows that the export trade of bamboo in 2007 reached US\$ 94 million. The characteristic of bamboo industries in Indonesia is labor intensive. In Tasikmalaya Regency, West Java Province, it employs more than 17,000 people and 8,500 workers only in Bangli Regency, Bali (Ekawati \& Sidabutar, 2015). In Gunungkidul Regency, the bamboo industry creates more than 6,500 job opportunities, and at the provincial level, it opens more than 21,000 employment opportunities (Industry and Trade Service of Daerah Istimewa Yogyakarta, 2016)

At the regency level, bamboo has been stipulated as a prioritized NWFP (Decree of Gunungkidul Regent No. 297/KPTS/2014 2014). As a part of government support for bamboo industries, some artisan groups are supervised (see Figure 1), although more artisans are running their business independently. In Gunungkidul, small-scale bamboo enterprises are developing. This research will address the structure of bamboo value chains. Firstly, the research examines the Gunungkidul Regency, through an overarching value chain mapping (the business practices and characteristics of each actor along the chains) and value chain dynamics (value chain type, product flow, financial flow, information flow, and value chain governance). Secondly, this research examines the social constraints, aspects that influence suboptimal policies to foster bamboo small-medium enterprise (SME) development.

Many studies about bamboo have been carried out in Indonesia. However, these studies emphasize two topics related to the economic contribution of bamboo business for actors' livelihoods and the growth of bamboo stands. Studies focusing on value chains remain limited. In 
addition, one bamboo product viz. the chemically treated bamboo we chose is a unique product, rare, and poorly studied. Therefore, conducting research on the value chain structure of bamboo products enriches perspectives on small and medium scale bamboo industries, especially in the tropics.

\section{Materials and Methods}

\subsection{Data Collection}

The research was conducted in Gunungkidul Regency, Yogyakarta Special Province, in Java Island (Figure 1). We gathered primary data through field observation and in-depth interviews from a total of 86 respondents. Field observation was performed throughout Gunungkidul Regency to help us characterize bamboo enterprises. It also gives us more of a sense of place and provides an essential step before deciding the form of bamboo enterprises to focus on. We focus on three bamboo products, viz. chemically treated bamboo, kitchen utensil, and toy handicraft (see Figure 2). The locations are Patuk, Rongkop, and Semin Districts (see Figure 1). Regarding the variety of bamboo products from Gunungkidul, we chose these products because they represent different sub-regencies and processing methods.

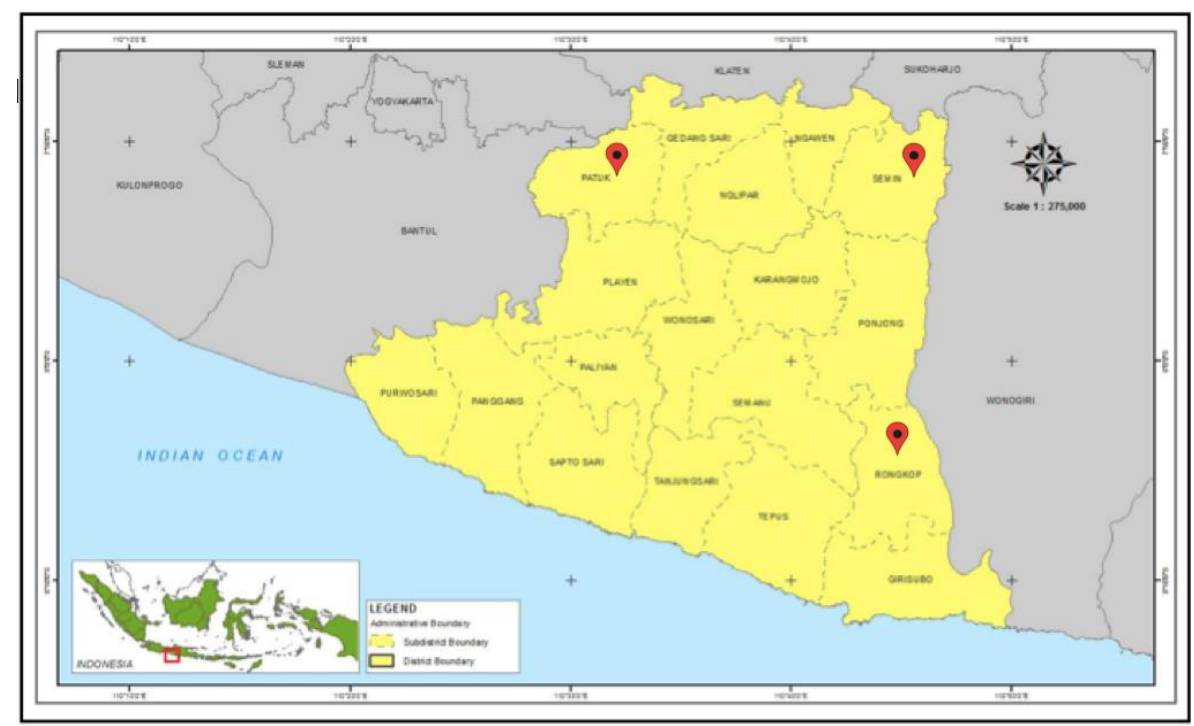

Figure 1. Map of Gunungkidul Regency



Figure 2. Three Bamboo Products from Gunungkidul 
There are a variety of products from artisans, and we specified which product to focus on. The kitchen utensil artisans in Rongkop Sub-Regency are skillful at creating numerous bamboo products, such as placemats, bulb frames, laundry baskets, disposal bins, tampah, and tambir. We only focused on the last two products because artisans only produce these products routinely, and we referred to them collectively as kitchen utensils. Others are based on order. Similar to kitchen utensil artisans, toy handicraft artisans can also create numerous products. We focused on four products, viz. duck whistles, bird whistles, spin knockers, and flutes. With or without advance contracts, artisans continue to produce these products.

The bamboo species used for each artisan is different. The chemically treated bamboo artisan group uses black bamboo (Gigantochloa atroviolaceae Widjaja), string bamboo (Gigantochloa apus), and giant bamboo (Dendrocalamaus asper). It all depends on customers' preferences. For kitchen utensil artisans, they utilize string and black bamboos. Toy handicraft artisans only use wuluh bamboo (Schizostachyum blumei). This bamboo species is relatively rare because it is fragile and cannot be used for construction.

To gather more reliable data and information, building rapport for a comfortable interview is vital. Therefore, we mix "Javanese Krama Inggil" a`nd "Javanese Kromo Alus" languages during the interview to show respect for elderly people. This language element is crucial when we conduct social science research in the region with deep roots in Javanese culture.

We performed the snowball approach to be able to map the production to consumption chains. Preceding respondents provided contact information on the next respondents (Noy, 2008). The reliable data was deemed achieved when no new answers and/or information was provided by respondents in the same node (Guest, Bunce, \& Johnson, 2006) and when interviewees' data were consistent (Alexiades \& Sheldon, 1996). We applied data source triangulation through the approach introduced by (Denzin, 2017). We triangulated from whom the data were gathered.

\subsection{Analysis}

Firstly, from all the data among the 86 respondents we gathered information using the modified value chain research guideline developed by Collins, Dent, and Bonney (2016). We performed coding analysis that consists of "open, axial, and selective coding" (Creswell \& Poth, 2016). Secondly, we applied the value chain approach in this research, which helps us identify the issue along the chains (Badar, 2015). This approach enables us to use several analyses, viz. (1) technical analysis to depict the flow of production process, (2) functional calculations to explain actors' activities within the chain, (3) institutional set-up analysis to describe the governance of each chain, and (4) output-input analysis to characterize the transformation of value-added. specifically for value chain governance, we use the proposed approach by Herr, Hultquist, Rogovsky, and Pyke (2006). Lastly, the descriptive analysis (Lawless \& Heymann, 2010) will be applied to discuss the social constraints, which makes policy was suboptimal to foster bamboo small-medium enterprise development.

\section{Results and Discussion}

\subsection{Value Chain of Three Bamboo Products in Gunungkidul}

Value chain comprises all activities taken to deliver service or product to the final consumer (Kaplinsky, 2000; Kaplinsky \& Morris, 2000). As a method, the value chain can present and account for the value creation of raw materials' transformation to the final product or service (Subramanian, 2007). As a tool, value chain analysis was used to achieve collaborative action between actors within the chain (Collins et al., 2016).

The three pictures below (Figure 3-5) depict the production to consumption flow of three bamboo products in Gunungkidul. Each actors on the chain will be explained on 3.2. 


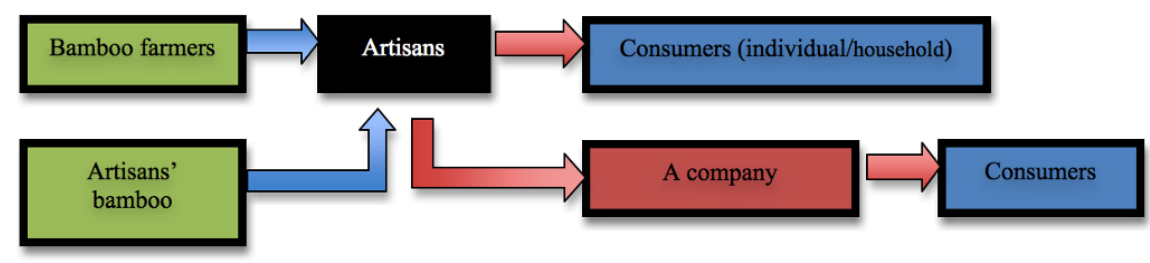

Information:

Bamboo as raw material

Bamboo as product

Figure 3. Chemically Treated Bamboo Value Chain in Gunungkidul

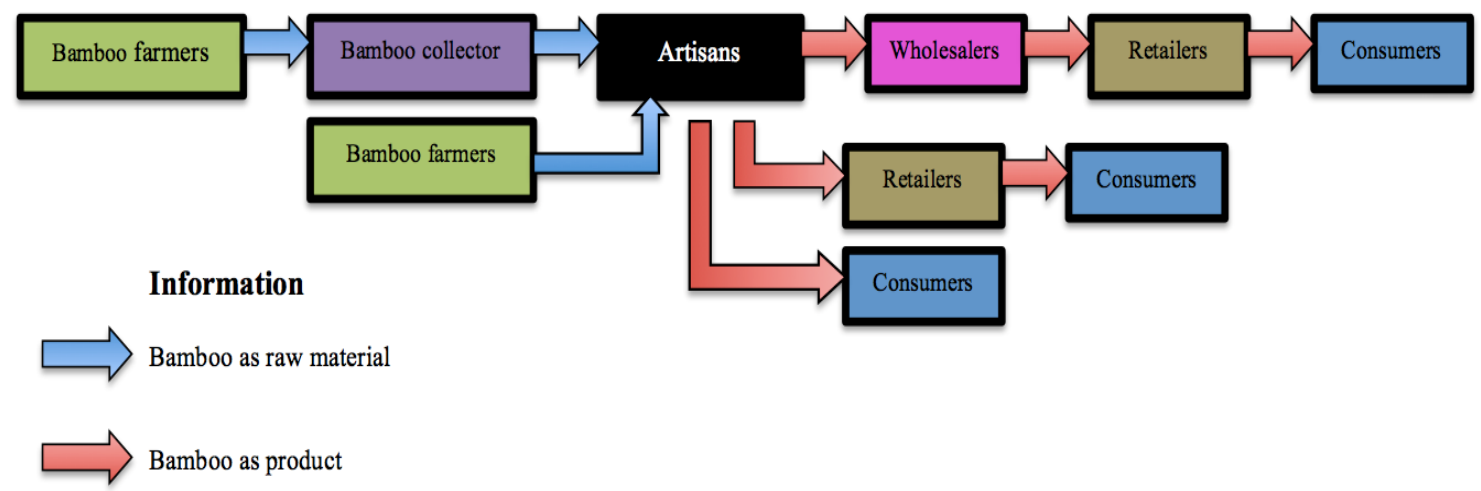

Figure 4. Bamboo Kitchen Utensil Value Chain in Gunungkidul

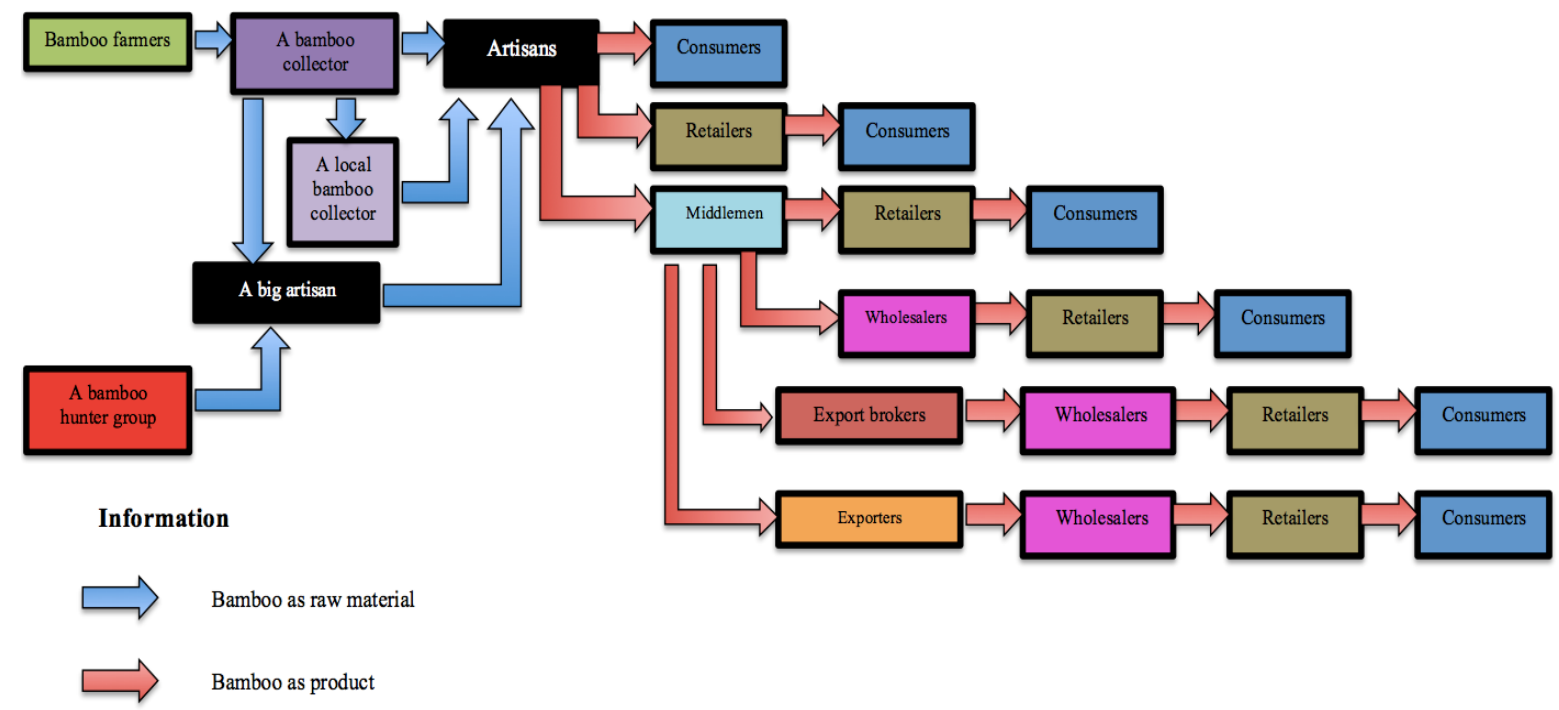

Figure 5. Bamboo Toy Value Chain in Gunungkidul

\subsection{The Business Practices and Characteristic of Each Actor Along The Chains}

\subsubsection{Bamboo Farmers}

Bamboo cultivators mostly do not manage bamboo stands intensively. Bamboo is not their primary commodity, as they prefer to grow paddy and focus on other jobs, especially as livestock breeders. Growers' activities include planting bamboo, harvesting bamboo when the buyer asks for it and negotiating bamboo poles' price. Some growers, especially growers of chemically treated bamboo material, manage the stands more intensively by adding dung. 


\subsubsection{Bamboo Hunters and Collectors}

Bamboo hunters exist in the bamboo toy handicraft chain, while bamboo collectors exist in the toy and kitchen utensil chains. There are two group classifications of the bamboo collector in the toy chain, viz. (1) collecting bamboo directly from farmers and (2) buying and reselling bamboo from the first group. Bamboo hunters' functions are similar to the first group of bamboo collectors. However, the source of bamboo is from forests. In the kitchen utensil chain, artisan and bamboo collectors conduct bamboo collection activities, with much bamboo supply provided by the artisans.

The bamboo collector's business activities consist of accepting contracts, seeking bamboo, negotiating the price of bamboo with farmers, harvesting bamboo, and delivering it to customers. Their business practices include placing orders, negotiating price, storing bamboo, and selling it to artisans for the local collector. As some bamboo for toys comes from state forests, the hunters usually pay a small sum of money to the forest ranger for the harvested bamboo. Some regions allow the hunter to utilize the bamboo freely, but not for some other areas.

\subsubsection{Artisans}

A chemically treated bamboo is a form of artisan group business, while the kitchen utensils and bamboo toy handicraft are household businesses. In household business, it is typical that each family member has a role during the production process. Each household tends to do the production and selling processes individually. The chemically treated bamboo business has been running for around ten years, kitchen utensils and bamboo toys have been running for more than 35 years with relatively the same products. In each bamboo enterprise in Gunungkidul, the business is usually initiated by several artisans, and then followed by the neighbors. It creates centers of the artisan at sub-village level. Chemically treated bamboo artisan group works by order, whereas kitchen utensils and bamboo toys create the products routinely. Artisans, mostly male artisans, also market the products as a retailer.

The artisans' business activities of each product are different. Activities of chemically treated bamboo artisans include accepting orders, seeking bamboo, cutting bamboo, and negotiating prices and deadlines. Some kitchen utensils and chemically treated bamboo artisans also have a role as bamboo growers. Once they get the bamboo, the artisan group transports it to the workshop. Once the chemical treatment finishes, some artisans transport it to the customers. In kitchen utensil chains, artisans buy the bamboo from the other artisans who have excessive bamboo stock or artisans who plant bamboo stands or from the collectors. Some artisans who have a more robust financial power sometimes have a role as a collector. Once the artisans finish the products, they sell them by themselves in traditional markets or sell them to retailers or wholesalers. In bamboo toy handicraft chains, artisans' business practices include accepting orders, buying bamboo by cash and/or bartering with the products, creating products, repacking, and sometimes transporting or posting them to retailers.

\subsubsection{Intermediaries}

Intermediaries only exist in the bamboo toy chain, and they act like a broker. Being a broker is a side job because the orders are uncertain. Their activities include product promotion, price and deadline negotiation, placing orders to the artisans, ensuring product quality, and order delivery.

\subsubsection{Retailers}

This actor only exists in bamboo toy handicraft and kitchen utensil chains. In the toy chain, some artisans and intermediaries also have a role as a retailer. They retail the products in two ways; traditional and modern. Traditional retailers commonly have weak financial power, and they retail the products through street vendors, motorcycle operators, pickup car operators, permanent storekeepers, temporary roadside stallholders, and handcart operators. The modern retailers, those who sell the product in a modern store, are not common. During the fieldwork, only one modern store sells bamboo toy handicrafts. In terms of retailing bases, there are local and non-local retailers. Traditional and non-local retailing types dominate the market of bamboo toy handicraft. In the kitchen utensil chain, the retailing process is more straightforward than the bamboo toy chain. The 
retailing process includes price negotiation, picking up products from artisans' houses, and selling the products using a motorcycle from one to another village.

Traditional retailers' business activities consist of price and deadline negotiation, placing orders, controlling quality, and selling the products. In contrast, a modern retailer tends to have a function to provide a place for the supplier to sell the products. It is a common form of business relationship in Indonesia, especially for cheap products. The modern retailer or store will get the profit from the increased prices.

\subsubsection{Wholesalers}

This actor is constantly active only in the bamboo toy handicraft chain. In the kitchen utensil chain, they are only rarely active. It ultimately does not operate in the chemically treated bamboo chain. Wholesaling activity depends on the demand, and each wholesaler applies different business strategies. For example, the wholesaler of Gunungkidul's flute in Bali adds a stamp "made in Bali" on the flute to add the value product. The wholesaler's business activities include promotion (not all wholesalers undertake this practice), accepting contracts, negotiating deadlines and prices, controlling quality, repacking, and transporting orders.

\subsubsection{Export Brokers}

This actor only exists in the bamboo toy handicraft chain. They usually have another role as an export-shipping provider. They capitalize on their relationship with importers who are attracted to numerous products of Indonesian handicrafts. For the first time, they promote bamboo handicrafts from Gunungkidul. An export broker's business practices include product promotion, price and deadline negotiation, accepting and placing orders to the artisans, controlling quality, repacking, arranging export documents, and transporting products to port. In bamboo toy handicrafts, each node of the actor has opportunities to be a broker. In the export market, the role of the export broker is vital.

\subsubsection{Exporters}

The actors sell bamboo products and handicrafts from other green materials such as rattan, coconut shells, and leaves. This actor only exists in the bamboo toy handicraft chain. To ensure the quality of the products, exporters have a trusted middleman or supplier for each product. They realize that foreign markets demand high-quality products. Therefore, the price paid for each product's artisans is higher than the cost of the product for domestic markets, which do not require a rigid standard.

The exporter's business practices consist of promotion via website and exhibitions, price, and deadline negotiations, accepting and placing orders, repacking, arranging export documents, and delivering products to an export shipping office.

\subsubsection{Customers}

In each bamboo product, the buyer's characteristics varies depending on the attached values of each product. Buyers trust the quality of chemically treated bamboo and believe in its ability for high-risk construction purposes. Daily function drives customers to buy kitchen utensils, whereas leisure purposes lead customers to purchase bamboo toy handicrafts. For high-risk products like chemically treated bamboo, buyers usually think twice before deciding to buy. For low-risk products such as bamboo toy handicrafts and kitchen utensils, that is not the case. Some buyers even purchase these products to express sympathy with the sellers and/or preserve the local product as a part of local heritage. The buyers' business activities include price selecting product, price and deadline negotiations, placing orders, and buying products.

\subsubsection{Government/Public Sector Service}

The government, either at the regency, provincial, or national levels, is an indirect actor within the chain. They provide support in several ways. The Forest and Plantation Service of Gunungkidul Regency has a riverbank re-greening program to increase bamboo supply to support bamboo- 
webbing industries. They focus on the bamboo provision tier. The Cooperative, Industry, and Trade Service conduct training regularly as part of their program to help artisans innovate products. They concentrate on the craftsperson empowerment tier.

One form of support that the government can do is to support forest-based industry certification. Through this scheme, it could enhance the enterprise's image and open new relationships with potential buyers especially for the export market (Galati et al., 2017). This means the market could be further developed. However, the implementation of the scheme for the bamboo industry will be complex due to the high cost and the source of bamboo still dominantly relies on bamboo from micro-scale gardens owned by the community.

\subsection{Value Chain Dynamics}

\subsubsection{Types of Value Chains}

There are several chains in the way bamboo products reach customers. The categorisation of value chain type depends on how the linkages between actors in the chain work (Badar, 2015). The final target markets and where they sell to the final customers are the basis of the categorisation. The bamboo value chains in Gunungkidul include traditional, modern, and export. In the conventional chain, the final sellers market the products in a conventional manner with the final customers, both in urban and rural regions. For modern chains, traders sell the product in a modern store, and the target market is people in urban areas.

The traditional chain is dominant in kitchen utensil and bamboo toy markets. In the kitchen utensil market, only this value chain type exists. All three types of value chains exist both in chemically treated bamboo and bamboo toy markets. However, the modern chain is more dominant than the export chain in the chemically treated bamboo market. The order is opposite in the bamboo toy market.

\subsubsection{Product Flows}

The bamboo product transformations start with raw materials and end with final products. In the chemically treated bamboo chain, the artisan group processes bamboo from farmers into chemically treated bamboo. Products from the artisan group can be valued as a half-finished or finished product. Through design and assembly processes, chemically treated bamboo is sometimes used to build numerous designs, like a bamboo mosque in Malaysia and bamboo housing in Indonesia. The product flows of kitchen utensils and bamboo toy chains are similar. However, the completion in the artisan stage' process results in final products.

\subsubsection{Financial Flows}

In all Gunungkidul's bamboo value chains, cash flows from the final consumers to bamboo farmers. Financial flow forms can be spot cash, monetary advance, payment in advance, or credit.

The form of payment is different between chain actors. How strong the established trust among actors and/or kinship relationship determines the payment method. The credit payment method indicates a trust that has been established over time. All actors except farmers are familiar with working under contract. Overall, the downstream segment where the final products flow, payment methods are more various. Table 1 below summarizes the financial flows of the three-bamboo value chains in Gunungkidul.

\subsubsection{Information Flows}

The market information is well shared in the three bamboo chains. Each actor mostly knows where the markets of the next actors are. However, the price information is unequal. The providers ignore this issue as they only focus on sustaining their contracts or orders. When the market is for export, the intermediaries automatically adjust the price as the export market increase the selling price from the intermediaries. In terms of buyer's value attributes, information is well shared to meet the buyers' requirements. 
Table 1. Three bamboo value chains' financial flows in Gunungkidul

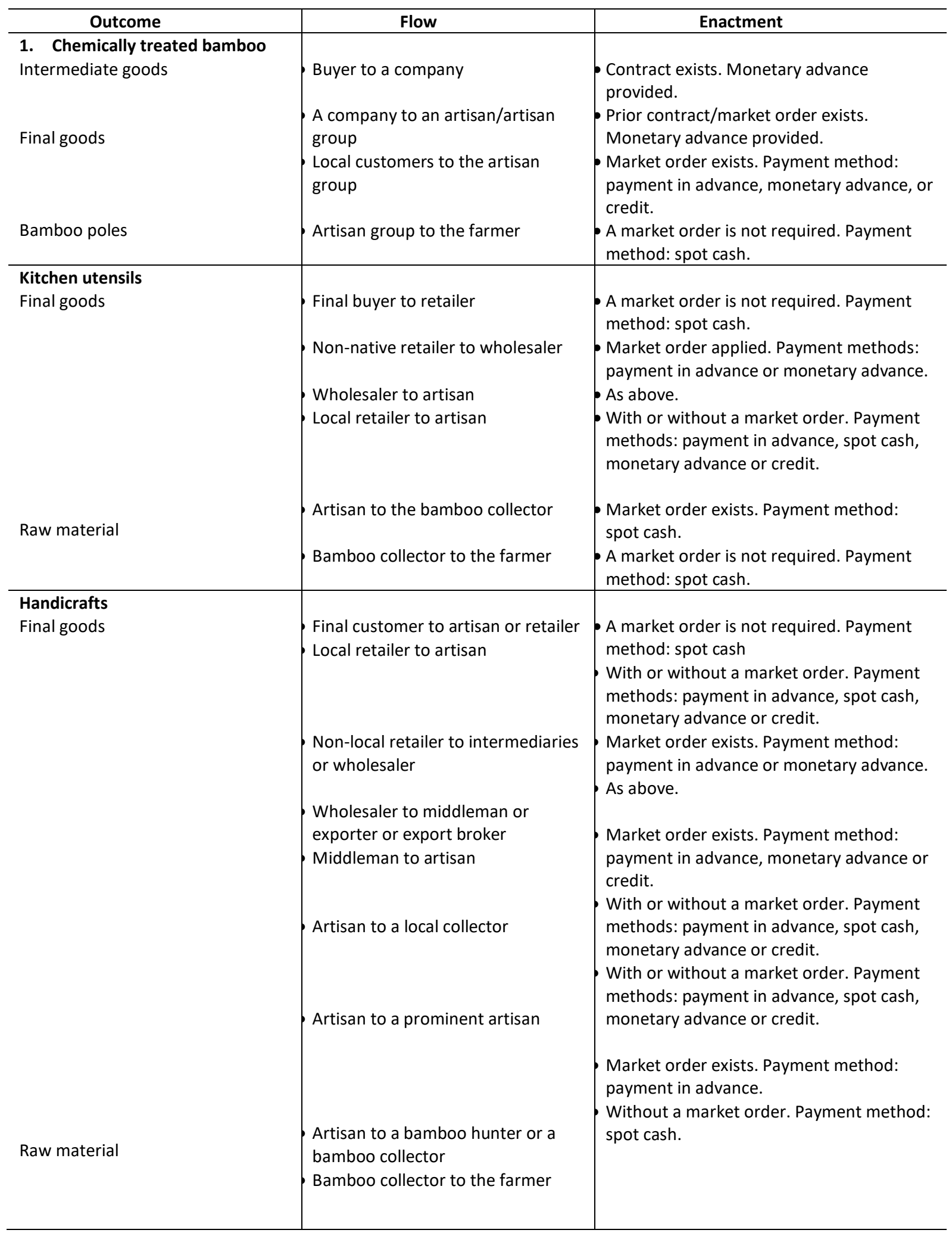

\subsubsection{Value Chain Governance}

Through value chain governance, we identified the relationship between actors in the chain. We applied the value chain governance type proposed by Herr et al. (2006), viz. (1) market-based, (2) balanced network, (3) directed network, and (4) hierarchy. There is no technical assistance, many customers and suppliers, and the possibility to repeat orders in a market-based form. In a balanced network, the providers have numerous customers; the information flow is intense, and both parties have the capability and commitment to cope with the problem by negotiation. There is imbalance 
in information in a directed network, with a primary buyer taking at least $50 \%$ of the product, and this buyer describes the goods and provides technical support. In the hierarchy, there is minimal autonomy at the local level to make decisions, and the buyer owns the supply materials. We only found the first three types in the chains (see Figure 6-8 below).

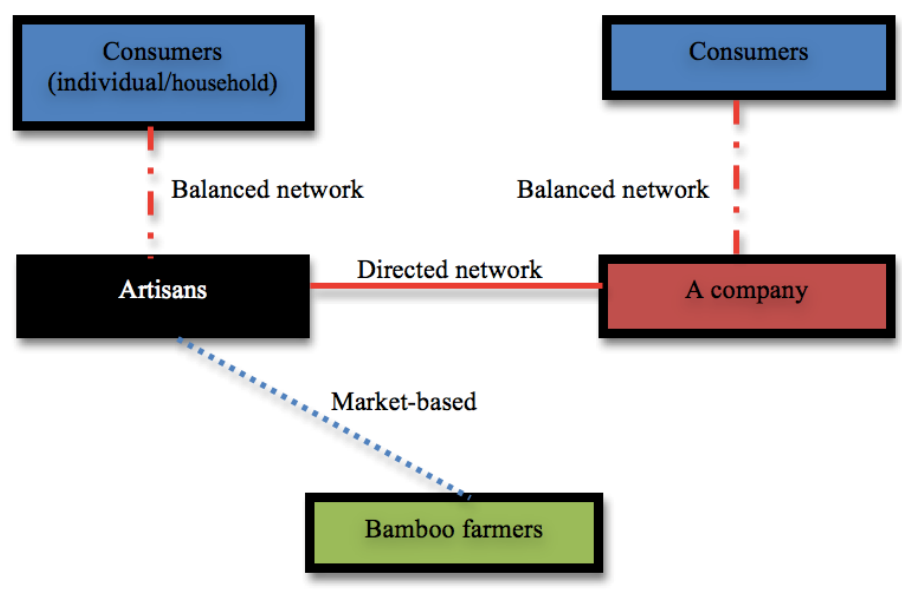

Information:

Bamboo as a raw material

․ Bamboo as a finished product

Figure 6. Value Chain Governance of Chemically Treated Bamboo

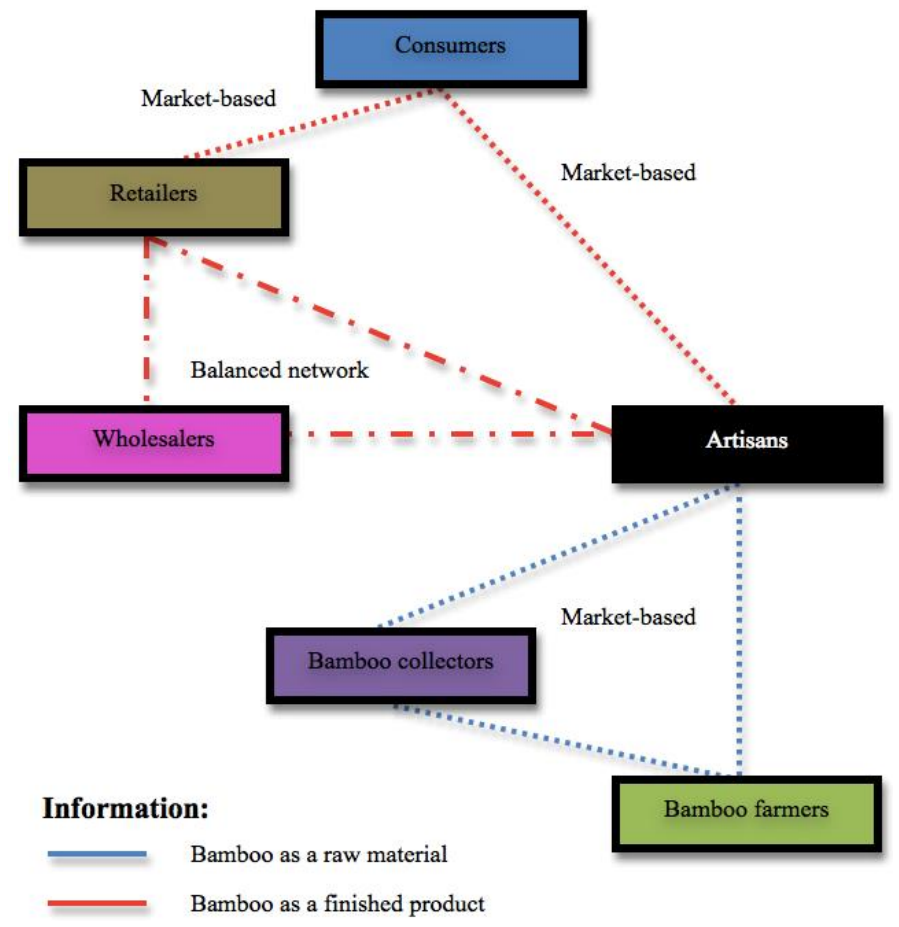

Figure 7. Value Chain Governance of Bamboo Kitchen Utensils in Gunungkidul

Governance has a close relation to power. There are two categories of power, viz. centered power and networked power (Hess, 2008). In centered power, there is an ability to control and dominate other value chain actors. In networked power, 'power is exercised through relationships between social actors, and the resources are becoming the medium. In this form, the relationship's power will determine how material, financial, and human resources flow and are allocated within the chains (Gereffi \& Korzeniewicz, 1994). At some point, the type of governance depends on the assurance incorporated in the network association rather than command and control (Hess, 2008). 
The value chain governance form can regulate the intervention schemes' achievement (Purnomo et al., 2009). Although buyers have power over the product along the three bamboo value chains, trust among parties has been widely established. It can be suggested from the balanced and directed network, which are dominant along the chains. This is positive for starting value chain improvement.

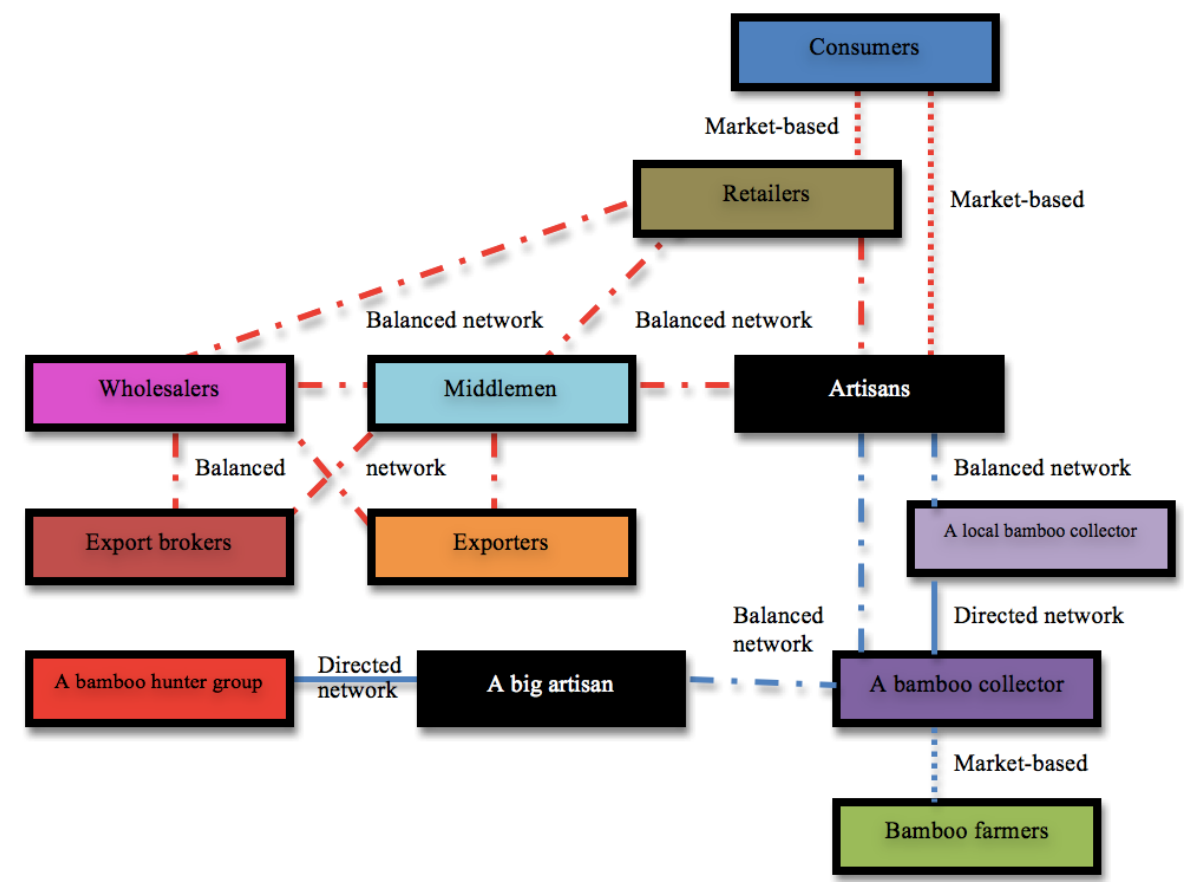

Figure 8. Value Chain Governance of Bamboo Toy in Gunungkidul

\subsection{Social constraint-policy nexus of the bamboo small-medium enterprise development}

Small-medium enterprises are a motor of rural economic development (Feranita, Nugraha, \& Sampir, 2020) and plays a significant role in developing countries (Abbasov \& Alizada, 2016). These enterprises are more resilient in sudden disturbances, like economic crises (Rosavina et al., 2019). Bamboo SMEs in Gunungkidul is proof of how SMEs in the creative industry passed through the hard economic shocks that happened in 1997-1998, 2008, and might be during the Covid-19 pandemic. With all of these positive characteristics, however, one major question arises: why do the development of these SMEs look slow? This section tries to answer this conundrum using a social lens. We argue that understanding social dimensions is fundamental to devise and initiate policy innovations and intervention

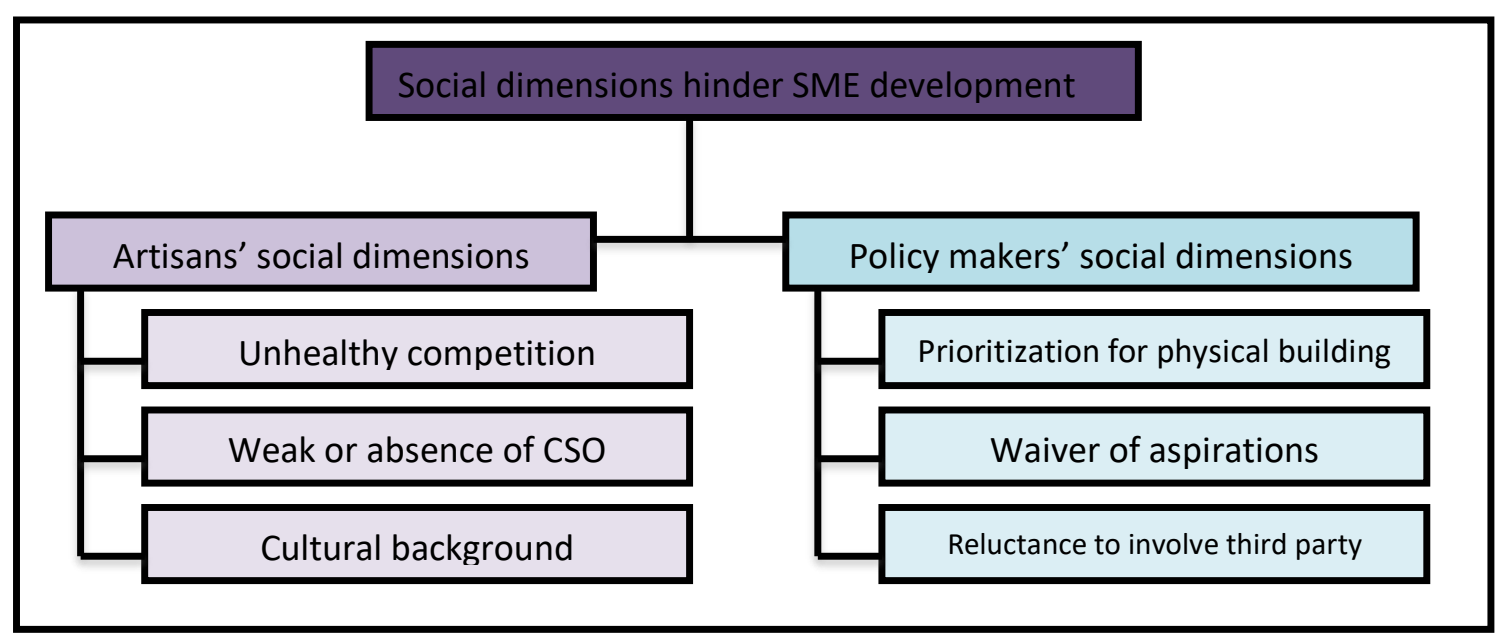

Figure 9. Social Dimensions Hinder SMEs Development 
Particular social dimensions hinder the development of SMEs under two categories, viz. policy makers' social dimension and artisans' social dimension (see Fig. 9). In general, constraints from policy makers' social dimensions exist commonly in all areas. For artisans', social dimensions do not necessarily exist in in every handicraft center. It tends to be case specific.

There are three main challenges in artisan nodes. The first one is unhealthy competition. On some occasions, in a handicraft center, where artisans work individually, price wars often occur. They compete for the same buyers and one party investigates the deal price between competitor and customer, followed by offering a cheaper price for this buyer and sometimes vilifying each other. This happens particularly for large orders. Relational environments like these will then make the process difficult to unite artisans in an organization. A strong civil society organization (CSO) is important to make their voices heard during the policy process, especially in the Global South (Start \& Hovland, 2004). The third constraint in SME development is cultural, integrated to the social lives and priorities of local communities. In Javanese, the culture of not chasing money very hard is prevalent. They do not push themselves to work so hard and make more money. They know when "enough is enough". At some point, this is good for balancing their working and social life. We can meet both artisans who have a strong passion to develop their business and those who are happy enough with their current business achievements.

In policy maker nodes, there are three main challenges. The central government devolves authority for village heads to maintain village funds (dana desa). It aims to spur development at the lowest governmental level. However, most of the fund is allocated to physical buildings like road facilities. Allocation to develop social capital seems to be very limited. In the Gunungkidul case, the physical capitals in Yogyakarta Special Province are relatively better than other provinces. Therefore, we argue that allocating some funds to foster bamboo SME, especially by strengthening SMEs collaboration, is essential. The second challenge is gathering aspirations from grassroots remains lacking. Ideally, village apparatus act as the first layer of the government to hear public voices and respond to their needs (Purwastuti \& Suwatin, 2011). This is called musyawarah desa (MUSDES) as the first process to devise and select development programs that will be conducted during the certain financial year. This should be a first step to propose programs related to SME development. The capacity and performance of local government is important in the decentralization era (Brinkerhoff \& Wetterberg, 2013). The last challenge is reluctance to involve third parties in devising the development agenda. The third party refers to researchers. Findings and policy recommendations proposed from research projects are often neglected in the policy process, even though policy stipulation requires a basis of evidence and sound research (Start \& Hovland, 2004). In many occasions, research findings gain limited currency in the process of guiding development projects.

Apart from the performance of the local government, the performance of the government at the top level is still not optimal in helping the development of bamboo SMEs. The project has not been able to change the three social barriers for bamboo craftsmen mentioned above and is still focused on increasing the capacity of individuals to improve their skills. Therefore, it will be easy to find highly skilled individuals, but the three social characteristics do not change much. Only individual craftsmen who are aware of how to develop will have the most positive impact from this government policy program. The coverage of the programs is also limited due to the limitation of government funding. Not all artisan groups are under supervision of the government.

\section{Conclusions}

The structure of the bamboo chains examined in this research depends on the number of stakeholders involved. The bamboo toy handicraft chain has the highest number of actor levels. As a consequence, this chain becomes the longest chain. In contrast, the chemically treated bamboo has the least number of actor levels and the shortest chain. The kitchen utensils and bamboo toy chain has a traditional chain. Meanwhile, modern chain type is more dominant in chemically treated bamboo chains.

The length of the chain influences the production flow. Therefore, most channels exist in the bamboo toy handicraft chain, and the least channel is in the chemically treated bamboo chain. In 
terms of financial flows, the forms of payment varies; including spot cash, credit, monetary advance, and payment in advance. In chemically treated bamboo chains, the cash advance is the most common, whereas, in the kitchen utensil chain, spot cash, payment in advance, and monetary advance are prevalent. Lastly, payment in advance and monetary advance are dominant. In terms of information flow, there is an imbalance in pricing shared information within the three chains. The forms of value chain governance vary, dominated by a stable network and market-based influences. The directed network is still found in chemically treated bamboo and bamboo toy handicraft chains.

In the raw material segment, collaboration among actors remains weak particularly when the market-based governance exists. Moreover, this is true when the flow of information is not well shared. This indicates that disadvantaged actor(s) exist in each bamboo chain in Gunungkidul. Through this study, actors within the chains could better understand the challenges to develop a certain bamboo-product chain. Each actor also had the opportunity to learn how to improve their performance and create values attached by the market and create more robust collaboration with other actors. This provided insights into ways for making the business relationships more sustainable. Policy efforts from the government in assisting the development of bamboo SMEs still encounter various obstacles, namely (1) development program policies at the local level that have not reflected or facilitated the aspirations of craftsmen and (2) positive program policies for the development of bamboo SMEs that are still limited and have not reached all groups of craftsmen. This second point sometimes has a positive impact that is not sustainable due to the lack of a strong desire from individual to further develop or scale up their businesses. From this research, it could ease the process of delivering public services by the local government in supporting bamboo enterprises in Gunungkidul Regency. Information from this study could be leveraged to modify the current approach of support programs and initiate more proper actions.

Limitations of this study are related to the limited number of bamboo-based products discussed. From dozens of products from Gunungkidul Regency, only three products were elaborated through this study. In order to create a more comprehensive policy targeted at market development of bamboo products and value chain improvement, understanding the current condition of each chain is important. Each bamboo product chain has its characteristics and perhaps requires a different approach for its development. In addition, future research should investigate the value chains of other bamboo-based products in Gunungkidul Regency. Such information about the condition of bamboo businesses throughout Gunungkidul Regency can thus be revealed completely and help to facilitate subsequent policy and programmatic interventions. This bamboobased creative business sector is still very relevant for study considering its profound impacts on the rural economy.

Author Contributions: The first author is responsible for overall conceptualization, methodology, validation, investigation, writing of the original draft, and writing the review and editing stages. The second author contributed on the investigation, validation, writing of the original draft, and visualization sections. The third author is responsible for writing, review, and editing, supervision, and funding acquisition.

Conflicts of Interest: The authors declare no conflict of interest.

Acknowledgments: We would like to thank the late Mr. Benyamin Jatiyuwono and Mr. Henricus Tegar who helped during the data collection process. We also owe our gratitude to government officials of BPPTA Ciamis, Forestry Service of Gunungkidul, SME Service of Gunungkidul, and all respondents for their support. We would like to extend our sincere thanks to our colleague Julie Watson for proofreading our manuscript.

\section{References}

Abbasov, A., \& Alizada, T. (2016). Small and medium-sized enterprises as an influential factor towards the economic growth of countries with transition economies. Economic and Social Development: Book of Proceedings, 453.

Alexiades, M. N., \& Sheldon, J. W. (1996). Selected guidelines for ethnobotanical research: a field manual. 
Ambrose-Oji, B. (2003). The contribution of NTFPs to the livelihoods of the'forest poor': evidence from the tropical forest zone of south-west Cameroon. International Forestry Review, 5(2), 106117. https://doi.org/10.1505/IFOR.5.2.106.17420

Anitha, V., Muraleedharan, P., Santheep, K., Thomas, S., \& Sreelakshmi, M. (2008). A planned market intervention for the bamboo sector of Kerala. Indian Journal of Agricultural Economics, 63(9022016-66773)

Arnold, J. M., \& Pérez, M. R. (2001). Can non-timber forest products match tropical forest conservation and development objectives? Ecological economics, 39(3), 437-447. https://doi.org/10.1016/S0921-8009(01)00236-1

Arshad, M., \& Reza, S. (2012). Socio-Economic Benefits Derived by Poor Rural Producers from Bamboo Value Chain Up-gradation: A study of Tripura, Northeast India. Indian Streams Research Journal, 2(4), 1-4.

Badar, H. (2015). Value chain performance improvement for sustainable mango industry development in Pakistan. (PhD), University of Queensland, Queensland.

Belcher, B., Ruíz-Pérez, M., \& Achdiawan, R. (2005). Global patterns and trends in the use and management of commercial NTFPs: implications for livelihoods and conservation. World development, 33(9), 1435-1452. https://doi.org/10.1016/j.worlddev.2004.10.007

Benton, A. (2014). INBAR Working Paper No. 76 - Greening Red Earth-Restoring landscapes, rebuilding lives.

Bhattacharya, P., \& Hayat, S. F. (2004). Sustainable NTFP management for rural development: a case from Madhya Pradesh, India. International Forestry Review, 6(2), 161-168. https://doi.org/10.1505/ifor.6.2.161.38399

Brinkerhoff, D. W., \& Wetterberg, A. (2013). Performance-based public management reforms: experience and emerging lessons from service delivery improvement in Indonesia. International Review of Administrative Sciences, 79(3), 433-457. https://doi.org/10.1177/0020852313491059

Collins, R., Dent, B., \& Bonney, L. (2016). A guide to value-chain analysis and development for overseas development assistance projects. ACIAR

Creswell, J. W., \& Poth, C. N. (2016). Qualitative inquiry and research design: Choosing among five approaches: Sage publications.

Denzin, N. K. (2017). The research act: A theoretical introduction to sociological methods: Transaction publishers.

Ekawati, D., \& Sidabutar, H. (2015). Model Capacity Building for Efficient and Sustainable Utilization of Bamboo Resources in Bangli District, Bali, Indonesia.

Feranita, N. V., Nugraha, A., \& Sampir, A. S. (2020). Effect of transformational and transactional leadership on SMEs in Indonesia. Problems and Perspectives in Management, 18(3), 415. https://doi.org/10.21511/ppm.18(3).2020.34

Fu, Y., Chen, J., Guo, H., Hu, H., Chen, A., \& Cui, J. (2009). Rain forest dwellers' livelihoods: income generation, household wealth and NTFP sales, a case study from Xishuangbanna, SW China. International Journal of Sustainable Development \& World Ecology, 16(5), 332-338. https://doi.org/10.1080/13504500903198805

Galati, A., Gianguzzi, G., Tinervia, S., Crescimanno, M., \& La Mela Veca, D. S. (2017). Motivations, adoption and impact of voluntary environmental certification in the Italian Forest based industry: The case of the FSC standard. Forest policy and economics, 83, 169-176. https://doi.org/10.1016/j.forpol.2017.08.002

Gereffi, G., \& Korzeniewicz, M. (1994). Commodity chains and global capitalism: ABC-CLIO.

Guest, G., Bunce, A., \& Johnson, L. (2006). How many interviews are enough? An experiment with data saturation and variability. Field methods, 18(1), 59-82. https://doi.org/10.1177/1525822X05279903

Herr, M. L., Hultquist, I., Rogovsky, N., \& Pyke, F. (2006). A guide for value chain analysis and upgrading. Geneva: ILO.

Hess, M. (2008). Governance, value chains and networks: an afterword. Economy and Society, 37(3), 452-459. https://doi.org/10.1080/03085140802172722 
Heubach, K., Wittig, R., Nuppenau, E.-A., \& Hahn, K. (2011). The economic importance of non-timber forest products (NTFPs) for livelihood maintenance of rural west African communities: A case study from northern Benin. Ecological economics, 70(11), 1991-2001. https://doi.org/10.1016/j.ecolecon.2011.05.015

Humphrey, J., \& Navas-Alemán, L. (2010). Value chains, donor interventions and poverty reduction: A review of donor practice. IDS Research Reports, 2010(63), 1-106. https://doi.org/10.1111/j.2040-0217.2010.00063_2.x

Humphrey, J., \& Schmitz, H. (2002). How does insertion in global value chains affect upgrading in industrial clusters? Regional studies, 36(9), 1017-1027. https://doi.org/10.1080/0034340022000022198

INBAR. (2009). INBAR Annual Report 2009: INBAR.

Industry and Trade Service of Daerah Istimewa Yogyakarta. (2016). Survey report of small-medium enterprises in DIY Province. Yogyakarta: Industry and Trade Service of Daerah Istimewa Yogyakarta.

Ingram, V. (2010). Governing forest commons in the Congo Basin: The case of non-timber forest product value chains. Paper presented at the 13th Biennial conference of the international association for the study of the commons (IASC).

Kaplinsky, R. (2000). Globalisation and unequalisation: what can be learned from value chain analysis? Journal of development studies, 37(2), 117-146. https://doi.org/10.1080/713600071

Kaplinsky, R., Memedovic, O., Morris, M., \& Readman, J. (2003). The global wood furniture value chain: What prospects for upgrading by developing countries. UNIDO Sectoral Studies Series Working Paper.

Kaplinsky, R., \& Morris, M. (2000). A handbook for value chain research (Vol. 113): University of Sussex, Institute of Development Studies Brighton.

Kar, S., \& Jacobson, M. G. (2012). Market constraints in NTFP trade: household perspectives in Chittagong Hill Tracts of Bangladesh. International Forestry Review, 14(1), 50-61. https://doi.org/10.1505/146554812799973136

Lawless, H. T., \& Heymann, H. (2010). Descriptive analysis. In Sensory evaluation of food (pp. $227-$ 257): Springer.

Lobovikov, M., Ball, L., Paudel, S., Guardia, M., Piazza, M., Wu, J., . . Russo, L. (2007). World bamboo resources: a thematic study prepared in the framework of the global forest resources assessment 2005: Food \& Agriculture Org.

M4P. (2008). Making Value Chains Work Better for the Poor: A Toolbook for Practitioners of Value Chain Analysis, Version 3.

Mahapatra, A. K., \& Tewari, D. (2005). Importance of non-timber forest products in the economic valuation of dry deciduous forests of India. Forest policy and economics, 7(3), 455-467. https://doi.org/10.1016/j.forpol.2004.02.002

Mekonnen, Z., Worku, A., Yohannes, T., Alebachew, M., \& Kassa, H. (2014). Bamboo Resources in Ethiopia: Their value chain and contribution to livelihoods. Ethnobotany Research and Applications, 12, 511-524.

Mekonnen, Z., Worku, A., Yohannes, T., Bahru, T., Mebratu, T., \& Teketay, D. (2013). Economic contribution of gum and resin resources to household livelihoods in selected regions and the national economy of Ethiopia. Ethnobotany Research and Applications, 11, 273-288.

Mitchell, J., Keane, J., \& Coles, C. (2009). Trading up: How a value chain approach can benefit the rural poor. London: COPLA Global: Overseas Development Institute.

Moktan, M. R., Norbu, L., Dukpa, K., Rai, T. B., Dorji, R., Dhendup, K., \& Gyaltshen, N. (2009). Bamboo and cane vulnerability and income generation in the rural household subsistence economy of Bjoka, Zhemgang, Bhutan. Mountain Research and Development, 29(3), 230-240. https://doi.org/10.1659/mrd.00029

Noy, C. (2008). Sampling knowledge: The hermeneutics of snowball sampling in qualitative research. International Journal of social research methodology, 11(4), 327-344. https://doi.org/10.1080/13645570701401305 
Pande, S., \& Pandey, S. (2008). Bamboo for the 21st century. International Forestry Review, 10(2), 134-146. https://doi.org/10.1505/ifor.10.2.134

Peters, C. M., Gentry, A. H., \& Mendelsohn, R. O. (1989). Valuation of an Amazonian rainforest. Nature, 339(6227), 655-656. https://doi.org/10.1038/339655a0

Purnomo, H., Achdiawan, R., Parlinah, N., \& Irawati, R. (2009). Value chain analysis of furniture: action research to improve power balance and enhance livelihoods of small-scale producers.

Purwastuti, \& Suwatin. (2011). Local Government Innovation: Case of Gorontalo - Indonesia. International Journal of Policy Studies, 2(2), 11.

Quang, D. V., \& Anh, T. N. (2006). Commercial collection of NTFPs and households living in or near the forests: Case study in Que, Con Cuong and Ma, Tuong Duong, Nghe An, Vietnam. Ecological economics, 60(1), 65-74. https://doi.org/10.1016/j.ecolecon.2006.03.010

Rana, M. P., Mukul, S. A., Sohel, M. S. I., Chowdhury, M. S. H., Akhter, S., Chowdhury, M. Q., \& Koike, M. (2010). Economics and employment generation of bamboo-based enterprises: a case study from eastern Bangladesh. Small-Scale Forestry, 9(1), 41-51. https://doi.org/10.1007/s11842009-9100-8

Rao, I., Kumar, A., Reza, S., \& Motokuri, B. (2009). A Pathway out of Poverty. Bamboo Incense Sticks Production as a Livelihood Option for Rural Women in Tripura, India. International Network for Bamboo and Rattan (INBAR) and Beijing and Centre for Indian Bamboo Resource and Technology (CIBART), New Delhi, 7-39.

Rich, K. M., Ross, R. B., Baker, A. D., \& Negassa, A. (2011). Quantifying value chain analysis in the context of livestock systems in developing countries. Food Policy, 36(2), 214-222. https://doi.org/10.1016/j.foodpol.2010.11.018

Rosavina, M., Rahadi, R. A., Kitri, M. L., Nuraeni, S., \& Mayangsari, L. (2019). P2P lending adoption by SMEs in Indonesia. Qualitative Research in Financial Markets.

Sadilah, E. (2010). Industri Kreatif Berbasis Ekonomi Kreatif. Ekonomi Kreatif, 720.

Schreckenberg, K., Marshall, E., Newton, A., Te Velde, D., Rushton, J., \& Edouard, F. (2006). Commercialisation of non-timber forest products: what determines success. ODI Forestry Briefing, 10, 1-6.

Start, D., \& Hovland, I. (2004). Tools for policy impact: a handbook for researchers: Overseas Development Institute London.

Subramanian, U. (2007). Moving toward competitiveness: A value chain approach (0821349392).

Sunderlin, W. D., Angelsen, A., Belcher, B., Burgers, P., Nasi, R., Santoso, L., \& Wunder, S. (2005). Livelihoods, forests, and conservation in developing countries: an overview. World development, 33(9), 1383-1402. https://doi.org/10.1016/j.worlddev.2004.10.004

Tewari, D. (1998). Income and Employment Generation Opportunities and Potential of Non-Timber Forest Products (NTFPs) A Case Study of Gujarat, India. Journal of Sustainable Forestry, 8(2), 5576. https://doi.org/10.1300/J091v08n02_05

Tewari, D. (2000). Valuation of non-timber forest products (NTFPS) models, problems, and issues. Journal of Sustainable Forestry, 11(4), 47-68.

Van der Lugt, P. (2008). Design interventions for stimulating bamboo commercialization-Dutch Design meets bamboo as a replicable model. (PhD), Delft University, Delft.

Wang, G., Innes, J. L., Dai, S., \& He, G. (2008). Achieving sustainable rural development in Southern China: the contribution of bamboo forestry. The International Journal of Sustainable Development \& World Ecology, 15(5), 484-495. https://doi.org/10.3843/SusDev.15.5:9

Widjaja, E. A., \& Kartikasari, S. N. (2001). Identikit jenis-jenis bambu di Jawa. Bidang Botani Pusat Penelitian Biologi LIPI. Cibinong. hlm, 96.

Yadav, M., \& Dugaya, D. (2013). Non-timber forest products certification in India: opportunities and challenges. Environment, development and sustainability, 15(3), 567-586. https://doi.org/10.1007/s10668-012-9393-1 